Fallas-Madrigal, D., Castelo-Corona, A., Mejías, D., StephensCárdenas, S., Astorga-Arias, J., Molina-Quirós, J. L., \& Hernández, S. (2021). Diversity of white spot patterns in the eagle ray Aetobatus laticeps (Myliobatiformes: Aetobatidae) in the north Pacific coast of Costa Rica. Revista de Biología Tropical, 69(Suppl. 2), S267-S276. https://doi.org/10.15517/rbt.v69iS2.48323

https://doi.org/10.15517/rbt.v69iS2.48323

\title{
Diversity of white spot patterns in the eagle ray Aetobatus laticeps (Myliobatiformes: Aetobatidae) in the north Pacific coast of Costa Rica
}

\author{
Diego Fallas-Madrigal ${ }^{1,2}$; (DD https://orcid.org/0000-0001-9327-0752 \\ Alejandra Castelo-Corona ${ }^{3}$; (iD https://orcid.org/0000-0003-3378-4297 \\ Diego Mejías"; (D) https://orcid.org/0000-0002-0177-8274 \\ Steve Stephens-Cárdenas ${ }^{2}$; (D) https://orcid.org/0000-0002-6090-9158 \\ Jennyfer Astorga-Arias5; (D) https://orcid.org/0000-0002-8384-4342 \\ José L. Molina-Quirós1; (D) https://orcid.org/0000-0001-7163-6004 \\ Sebastián Hernández ${ }^{1,6}$; (D) https://orcid.org/0000-0002-2908-6050
}

1. Biomolecular Laboratory, Center for International Programs and Sustainability Studies, Universidad Veritas, San José, Costa Rica; niuvinor@gmail.com, jmolina@veritas.cr, shernandez@veritas.cr

2. Escuela de Ciencias Biológicas, Universidad Latina de Costa Rica, San José, Costa Rica; steve.stephens@ulatina.net

3. Tecnológico Nacional de México, Campus Bahía Banderas, Jalisco, México; alejandracasteloc@gmail.com

4. Locomotion Producciones, Guanacaste, Costa Rica; diegomejias@mac.com

5. School of Management and Spanish Department, California Lutheran University, Thousand Oaks, California, United States of America; astorgajennyfera@gmail.com

6. Sala de Colecciones, Facultad de Ciencias del Mar, Universidad Católica del Norte, Coquimbo, Chile.

Received 30-I-2021. Corrected 13-IV-2021. Accepted 12-VII-2021.

\begin{abstract}
Introduction: The Pacific white-spotted eagle ray Aetobatus laticeps, has recently separated from the Atlantic A. narinari based on both morphological and genetic evidence. This species is characterized by a dark body with numerous white spots all over its dorsal side. Considering the type, shape, number, and distribution of these natural markings as potential identifiers at the individual level, we studied the variation in the spot patterns.

Objective: Describe and compare the white spot pattern (type and distribution) of individuals and evaluate their potential use as identifiers at the individual level.

Methods: We analyzed 54 videos (105 subsequent extracted photos) and 19 photographic records that were taken at different sites along the Pacific coast of northern Costa Rica.

Results: Seventeen distinctive types of white spots were identified across the entire dorsal side of the rays. Significant differences between each major body section (pectoral fins, back, head, and pelvic fins) were found in the type and frequency of white spots. The type 'single spot' was commonly distributed across the entire dorsal side, and the spot pattern on the pelvic fins was informative to identify 72 individuals.

Conclusions: The analysis of the type, shape, and distribution of white spots in A. laticeps determined several combinations of white spot patterns that be used for further taxonomic description and provide potential identification of the individual for future population studies along with its distribution.
\end{abstract}

Key words: photo-ID; marks; morphology; Eastern Tropical Pacific; description; characterization; batoid. 
Assessment of the dynamics of the wild population for their management and conservation efforts requires information from the population trends, population sizes, and biological parameters, i.e., longevity, sexual maturity, and fecundity (Musick \& Bonfil, 2005; Porsiel, 2018). In this regard, the discrete characterization of the coloration pattern of a particular species and the identification of the population's members is imperative to appraise population constraints (Porsiel, 2018). For instance, mark and recapture methods have allowed individual identification and provided insights into the migration and behavior patterns in areas where species can be observed year-round, among other biological parameters (Cerutti-Pereyra et al., 2017; Flowers, Henderson, Lupton, \& Chapman, 2017; Sellas et al., 2015).

Invasive and non-invasive methods are used to tag individuals in the wild (Speed, Meekan, \& Bradshaw, 2007). Non-invasive methods such as pigmentation patterns and spotted mark analysis, serve to identify individuals, e.g., the jaguar Panthera onca (Linnaeus 1758) (Carrera-Treviño, Lira-Torres, Martínez-García, \& López-Hernández, 2016), the tiger Panthera tigris (Linnaeus 1758) (Ullas-Karanth \& Nichols, 1998), butterflies such as Heliconius charitonia ramsdeni Comstock \& Brown 1950 (Denis-Ávila \& CruzFlores, 2017), the whale shark Rhyncodon typus Smith 1828 (Andrzejaczek et al., 2016) and the spotted eagle ray Aetobatus narinari (Euphrasen 1790) (Bassos-Hull et al., 2014; González-Ramos, Santos-Moreno, RosasAlquicira, \& Fuentes-Mascorro, 2016). In the case of elasmobranch species, this method is less invasive and prevents large individuals from experiencing episodes of stress, altering their natural behavior and survival during the handling process (Porsiel, 2018).

The pigmentation pattern and other anatomical differences i.e., disc size, can vary through the distribution range of eagle rays (McEachran, De Carvalho, \& Carpenter, 2002) (Myliobatiformes: Aetobatidae). In Aetobatus (Aetobatidae), genus comprises five species distributed worldwide, where genetic studies reveal three allopatric species: A. narinari in the Atlantic, A. ocellatus (Kuhl 1823) in the Indo-West Pacific, and A. laticeps (Gill 1865) in the Eastern Pacific (Naylor et al., 2012; Richards, Henning, Witzell, \& Shivji, 2009; White, Last, Naylor, Jensen, \& Caira, 2010). The Pacific white-spotted eagle ray ( $A$. laticeps), display a bluish-black dorsal coloration with very noticeable and abundant white spots (Last et al., 2016). It is suggested that chromatic and other morphological traits denote distinct geographic units for the eagle ray $A$. narinari (McEachran et al., 2002; Sales et al., 2019). In addition, Sales et al. (2019) showed that males of $A$. narinari tend to have well-defined spots, whereas females present indistinct spots.

The North Pacific coast of Costa Rica is highly productive and dynamic due to its unique oceanographic characteristics, i.e., strong seasonal upwelling events, local and regional ocean currents, gyres, weather conditions, and ocean surface temperatures (Fiedler, 2002; Robertson \& Allen, 2015). This area has several year-round habitats for batoid species, e.g., Urotrygon spp. (Porsiel, 2018; Robertson \& Allen, 2015), revealing large aggregations within small shallow bays. However, other more mobile batoid species such as A. laticeps and Aetomylaeus asperrimus (Gilbert 1898) may occur seasonally (Chávez et al., in press). Here, we describe the diversity and distribution of white spots, and recaptured photo IDs based on the entire dorsal side, in specimens of $A$. laticeps from the North Pacific coast of Costa Rica.

\section{MATERIALS AND METHODS}

Data collection: A total of 54 independent videos (105 subsequent extracted photos) and 19 photographic records of $A$. laticeps were collected from 10 sampling sites distributed along the Pacific coast of northern Costa Rica from January 2015 to December 2019 (Table 1, Fig. 1). These recordings were taken on freediving surveys that ranged between 1 and $10 \mathrm{~m}$ depth, using a GoPro Hero 4 camera (GoPro Inc). On each dive, the entire dorsal side of 
each observed eagle ray was recorded. To capture the entire, white-spotted pattern, the videos were reviewed by targeting the frontal plane to the dorsal side of the individuals. Each captured video was standardized with the same recording quality properties $(1080 \mathrm{p} / 60 \mathrm{fps}$ videos). Because water turbidity can interfere with video quality, efforts were made to approach the eagle rays within $1 \mathrm{~m}$ to obtain the best possible image quality.

TABLE 1

Sampling sites where Aetobatus laticeps (Myliobatiformes: Aetobatidae) individuals were recorded along the Pacific coast of northern Costa Rica (2015-2019)

\begin{tabular}{|c|c|c|c|}
\hline \multirow{2}{*}{ Sites } & \multirow{2}{*}{ Abbreviation } & \multicolumn{2}{|c|}{ Coordinates } \\
\hline & & Latitude & Longitude \\
\hline Salinas Bay & SB & $11^{\circ} 2^{\prime} 11^{\prime \prime}-11^{\circ} 1^{\prime} 57^{\prime \prime} \mathrm{N}$ & $85^{\circ} 42^{\prime} 46^{\prime \prime}-85^{\circ} 42^{\prime} 5^{\prime \prime} \mathrm{W}$ \\
\hline Rajada Beach & $\mathrm{RB}$ & $11^{\circ} 1 ’ 39^{\prime \prime}-11^{\circ} 1^{\prime} 28^{\prime \prime} \mathrm{N}$ & $85^{\circ} 45^{\prime} 13^{\prime \prime}-85^{\circ} 45^{\prime} 3^{\prime \prime} \mathrm{W}$ \\
\hline Pilas Beach & PB & $11^{\circ} 0^{\prime} 46^{\prime \prime}-11^{\circ} 00^{\prime} 37^{\prime \prime} \mathrm{N}$ & $85^{\circ} 44^{\prime} 37^{\prime \prime}-85^{\circ} 44^{\prime} 29^{\prime \prime} \mathrm{W}$ \\
\hline Lora Island & LI & $11^{\circ} 0{ }^{\prime} 39^{\prime \prime}-11^{\circ} 04^{\prime} " \mathrm{~N}$ & $85^{\circ} 45^{\prime} 5^{\prime \prime}-85^{\circ} 44^{\prime} 58^{\prime \prime} \mathrm{W}$ \\
\hline Manzanillo Beach & MB & $11^{\circ} 0 ’ 28^{\prime \prime}-11^{\circ} 0 \prime 23^{\prime \prime} \mathrm{N}$ & $85^{\circ} 44^{\prime} 0 ”-85^{\circ} 43^{\prime} 54^{\prime \prime} \mathrm{W}$ \\
\hline Muñeco Island & MI & $10^{\circ} 59^{\prime} 7^{\prime \prime}-10^{\circ} 58^{\prime} 37^{\prime \prime} \mathrm{N}$ & $85^{\circ} 43^{\prime} 16^{\prime \prime}-85^{\circ} 42^{\prime} 43^{\prime \prime} \mathrm{W}$ \\
\hline Cornuda Island & $\mathrm{CI}$ & $11^{\circ} 0^{\prime} 17^{\prime \prime}-10^{\circ} 59^{\prime} 60^{\prime \prime} \mathrm{N}$ & $85^{\circ} 44^{\prime} 56-85^{\circ} 44^{\prime} 39^{\prime \prime} \mathrm{W}$ \\
\hline Matapalitos Beach & MPB & $10^{\circ} 56^{\prime} 6^{\prime \prime}-10^{\circ} 55^{\prime} 53^{\prime \prime} \mathrm{N}$ & $85^{\circ} 47^{\prime} 45^{\prime \prime}-85^{\circ} 47^{\prime} 18^{\prime \prime} \mathrm{W}$ \\
\hline Cocineras Island & $\mathrm{CI}$ & $10^{\circ} 51^{\prime} 17^{\prime \prime}-10^{\circ} 51^{\prime} 15^{\prime \prime} \mathrm{N}$ & $85^{\circ} 54^{\prime} 17^{\prime \prime}-85^{\circ} 54^{\prime} 13^{\prime \prime} \mathrm{W}$ \\
\hline Flamingo Sting Ray City & FSC & $10^{\circ} 26^{\prime} 46^{\prime \prime} 1^{\circ} 26^{\prime} 35^{\prime \prime} \mathrm{N}$ & $85^{\circ} 46^{\prime} 42^{\prime \prime}-85^{\circ} 46^{\prime} 33^{\prime \prime} \mathrm{W}$ \\
\hline
\end{tabular}

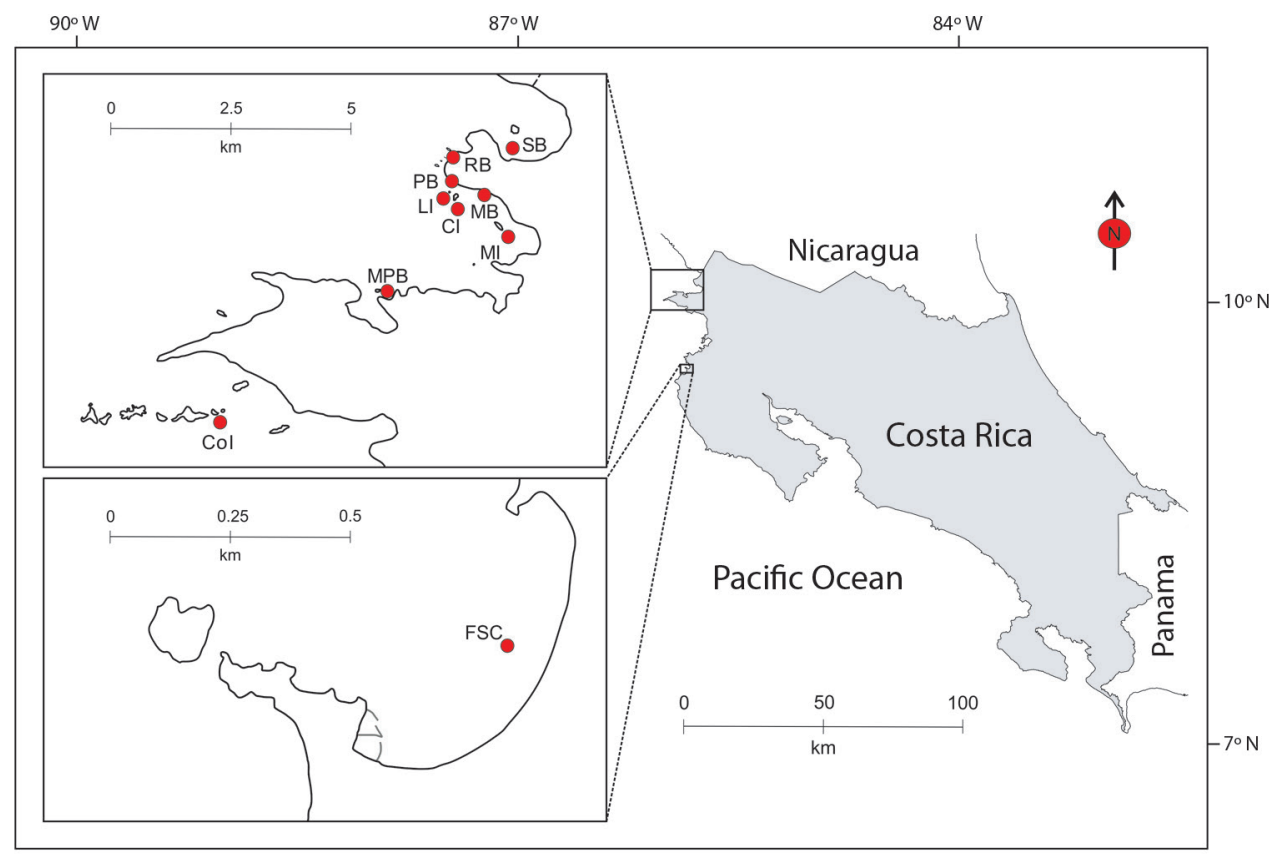

Fig. 1. Map of 10 sampling sites surveyed to obtain visual material from Aetobatus laticeps. These are: Salinas Bay (SB, N $=1$ ), Rajada Beach ( RB, N =2), Pilas Beach ( $\mathrm{PB}, \mathrm{N}=1)$, Lora Island (LI, N = 2), Manzanillo Beach (MB N = 17), Muñeco Island (MI, $N=27$ ), Cornuda Island ( $\mathrm{CI}, \mathrm{N}=9$ ), Matapalitos Beach (MPB, $\mathrm{N}=12$ ), Cocinera Island $(\mathrm{CoI}, \mathrm{N}=1)$, and Flamingo Sting Ray City (FSC, $\mathrm{N}=1$ ). The "N" means visual samples per site. 


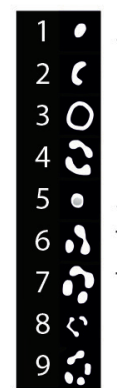

Single spot

Regular middle moon

Empty circle

Middle moons circle

Semi empty circle

Two single spots circle

Three single spots circle

Misshapen circle

Different spots circle

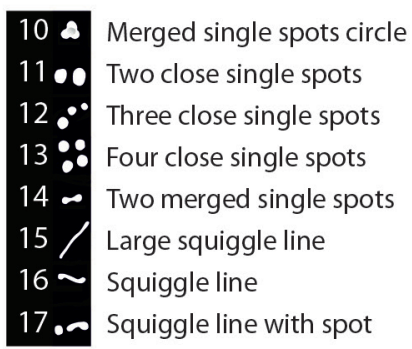

A

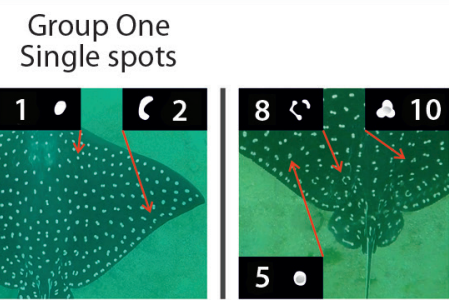

Group Three

Bond of spots
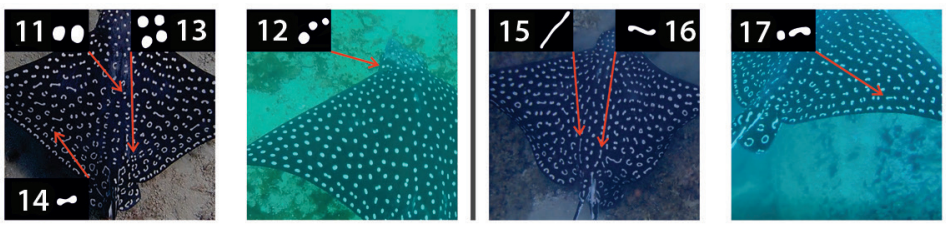

Fig. 2. White spot type diversity identified on the entire back side of Aetobatus laticeps. (A) shows the overall diversity of white spot types grouped according to their similarity. 1 and 2 are considered simpler white spot types while 3 to 17 are considered complex types. (B) individual examples showing each type of white spot pattern.

Data management and processing: The database included sampling sites, dates, and the number of videos or photos. Images were extracted and saved from each video. To identify the white spot diversity, an initial review of different white spot types was assessed, categorizing them into single component units, and groups (Fig. 2). These spot units were defined as conspicuous, distinctive, and uniform shapes that occur in A. laticeps dorsal patterns. Frequent white spot types were recognized e.g., 'single spot', 'two close single spots', 'two merged single spots' and 'semi-empty circle', and infrequent ones i.e., resting white spot types. Then, these white spots were counted for the entire dorsal side divided in four zones: pectoral fins, back, head, and pelvic fins (Fig. $3)$. All white spots were visually counted using the Adobe Photoshop CC 201732 bits software and, the frequency of occurrence of each spot type was calculated by zone.

Statistical analysis: The mean percentage of dominant spot type 'single spot', was used to test for statistical differences in left/right pectoral fins, as well as left/right sides of the back, using a univariate paired t-test implemented in Past 3 software (Hammer, Harper, \& Ryan, 2001). When no statistical differences were found between the right/left sections of pectoral fins and back, they were treated, in further analysis, as a single analytical unit, using mean values. For major pattern composition analyses, only 'single spot', 'two close single spots', 'two merged single spots' and 'semiempty circle' were included, as they were the most frequent patterns (cumulative frequency $\geq 80 \%$ ). Infrequent white spot patterns were 
excluded from the analyses ( $\leq 1 \%$ frequency). The pelvic fins and the head were excluded from this analysis given their relatively smaller size, proportion, and diversity of white spots, in contrast with the pectoral fins and back. In addition, an ANOVA test was used to determine the differences in the occurrence of white spots among body zones. For each test, when significant differences were detected, a Tukey post hoc HSD test was performed in order to identify specific differences between mean frequency values among body zones $(\alpha=0.05)$.

Differences in body zone based on the frequency of spot type and count were assessed with an Analysis of Similitude (ANOSIM) (Ornés, Herbst, Spillner, Mewes, \& Rauch, 2014). ANOSIM uses permutations to identify the similarity of samples within an assigned group, compared to samples from other groups (Tillett et al., 2011). A SIMPER test was then implemented to identify the spot-type frequencies generating observed differences (Fig. 3).

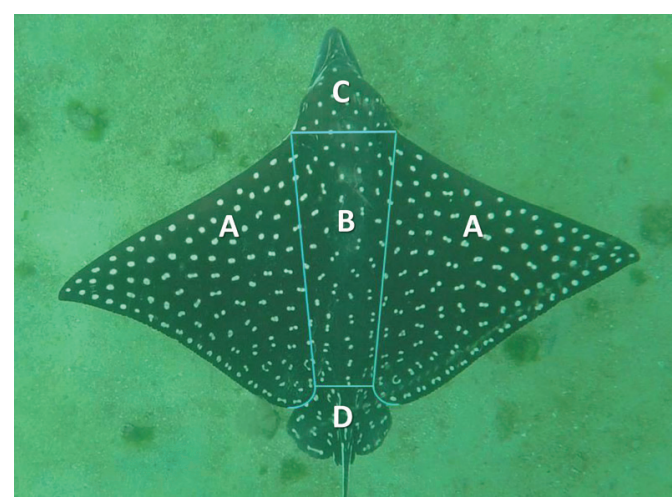

Fig. 3. Photo from the entire back side categorized by body zones, showing the pectoral fins (A), back (B), head (C), and pelvic fins (D).

Individual identification: Differentiation of individuals from total samples was performed by comparing the white spot pattern present on each pelvic fin by eye inspection.

\section{RESULTS}

A total of 124 photos of $A$. laticeps comprehended the database, i.e., 105 photos extracted from videos plus 19 photographic records. From this, 75 photos were assigned to different individuals, comprising 72 individuals and 3 recaptures. Due to high-quality resolution and accuracy to identify white spots, only 62 photos-different individuals were used for further analysis. Seventeen distinctive types of white spots were identified and grouped in four categories (Fig. 2). Not all eagle rays had the same 17 white spot types (Table S1). Some white spot types i.e., 'single spot', 'two close single spots', 'two merged single spots', and 'semi-empty circle' (Fig. 2) were more frequent than others. The most frequent white spot type for each zone was 'single spot', with a value close to $97 \%$ for the head, followed by $63 \%$ for the back, $55 \%$ for the pectoral fins, and 28 $\%$ for the pelvic fins.

When comparing right and left 'single spot' frequency, no significant differences were found in both pectorals $(\mathrm{T}=0.250$, d.f. $=1.212$, $\mathrm{P}=0.803)$ and back-sides $(\mathrm{T}=0.065$, d.f. $=$ $0.487, \mathrm{P}=0.949$ ), therefore pectoral and back zones were considered as two single units. ANOVA and Tukey tests identified significant differences in the frequencies of three out of the four most common white spot patterns (Table $\mathrm{S} 2)$. For both 'single spot' $(\mathrm{F}=86.040$, d.f. $=$ $3, \mathrm{P}<0.001)$ and 'two close single spots' $(\mathrm{F}=$ 26.890 , d.f. $=3, \mathrm{P}<0.001$ ), frequencies differed in all body zone pair comparisons except, for pectoral fins and back. The 'single spot' was the dominant spot type on the head of each individual sampled. For 'two merged singles spots' $(\mathrm{F}=29.630$, d.f. $=3, \mathrm{P}<0.001)$, the head presented significant differences with every other body zone, as this spot type had significantly low frequencies when compared to other body zones. For 'semi-empty circle' spots, the ANOVA test was performed excluding the head section category, as it showed extremely 


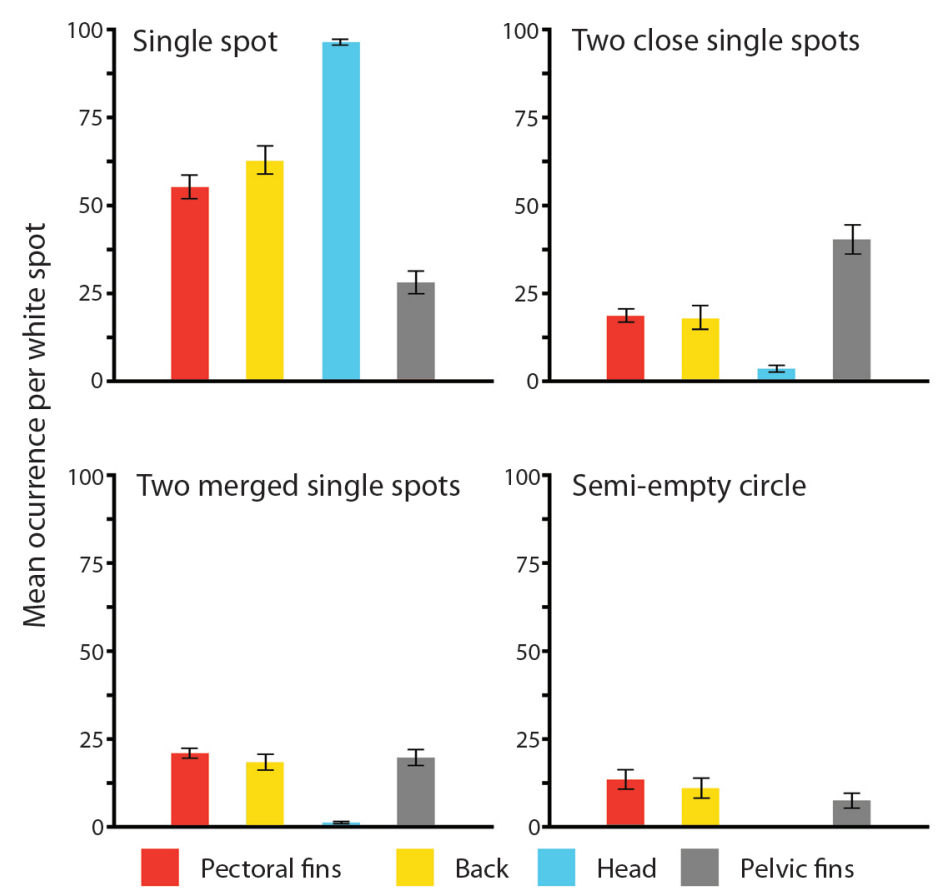

Fig. 4. Bar plots presenting the mean occurrence of the four most representative white spot types among body zones. Being pectoral fins (-), back (-), head (-), and pelvic fins (-).

low frequencies of the pattern $(<0.1 \%)$. The results showed no statistical differences in the frequencies among body zones $(\mathrm{F}=1.47$, d.f. $=$ $3, \mathrm{P}=0.23$ ) (Fig. 4).

The ANOSIM test identified overall differences in body zones associated with the occurrence of the four most frequent white spot types (Global $\mathrm{R}=0.349, \mathrm{P}=0.001)$. SIMPER analysis showed differences in the cumulative contribution of each white spot type between each body zone, i.e., 'single spot' (43.690 $\%)$, 'two close single spots' $(20.290 \%)$, 'two merged single spots' $(18.680 \%)$, and 'semiempty circle' (17.340\%) (Fig. 4, Table S3). The 'single spot' type was the most frequent spot type in every area tested (mean range 28 $\%-98 \%$ ), followed by 'two close single spots' (mean range $2.080 \%-24.800 \%$ ), and 'two merged single spots' (mean range $0.580 \%$ $17.900 \%$ ). 'Semi-empty circle' was the least common spot type of the major spot pattern components (mean range $0.07 \%-11.4 \%$ ).
Overall, most individuals were recognized based on their pelvic fins and successfully confirmed using the white spot pattern. From the 75 photos used for identification, two samples were absent of visually identifiable spot patterns on pelvic fins, requiring the identification of the individual to come from the white spot pattern of the entire dorsal side. Individual differentiation analysis based on the white spot pattern recognized 72 different eagle rays and 3 recaptured individuals detected from the videos/photos.

\section{DISCUSSION}

Our results provide novel information on the diversity of white spots of A. laticeps, determining several combinations that should be considered for a better taxonomic description (Gill, 1867; Last et al., 2016). To date, these descriptions considered only single white spots on the dorsal surface without mentioning 
the different types and shapes that can be found. This diversity found is characterized by many 'single spots' on their pectoral fins, back, and head zones, while the pelvic fins have a greater distribution of complex types of spots.

Pelvic fins are a natural marker to recognize individuals by providing a type of fingerprint for their identification. These fingerprinting marks make it easier to determine whether an individual has already been identified or not (recaptured). In this context, we successfully recognized more than 70 unique individuals based on the white spot pattern in the pelvic fins from the individual's videos/ photos. Furthermore, identifying samples with white spot patterns of the entire dorsal side was also successful due to the different patterns shown between individuals.

The study of these morphological features can provide important data such as population dynamics that could help to solve some taxonomic problems (Palmeira \& Rosa, 2014). Furthermore, a study of the differences in white spot pattern between sexes would be useful. However, this was not studied due to the unreliable observation of the absence or presence of claspers in most individuals. It is important to note that, although not part of this study, we found some individuals $(\mathrm{N}=4)$ with black underlying edges from the pectoral tip on the ventral body side to the dorsal side. This is considered to be unusual (Last et al., 2016) and is likely common in neonates and juvenile individuals. Therefore, a better morphological description is needed, considering more distant sites from the continental distribution from Mexico to Ecuador, as well as its oceanic island distribution e.g., Cocos Island (Costa Rica).

Also, several pictures of Aetobatus individuals have revealed an additional putative eagle ray species from Cocos Island based on the white spot pattern. Video and pictures recorded from several eagle rays evidence a greyish dorsal coloration with numerous small white spots (a minimized version of 'single spot' in A. laticeps). The anterior edges from the pectoral fins show the absence of white spots, the posterior edge has distinct rows of little white spots, and a moderately long fleshy rostral lobe (Fig. 5). This white spot pattern resembles its sister species, A. ocellatus. Considering that $A$. ocellatus has been previously documented in Cocos Island (Bussing \& López, 2005; Garrison, 2005); it is imperative to clarify the validity of the species of the Aetobatus complex along the Eastern Tropical Pacific. A comprehensive taxonomic study of this genera, contrasting morphological criteria
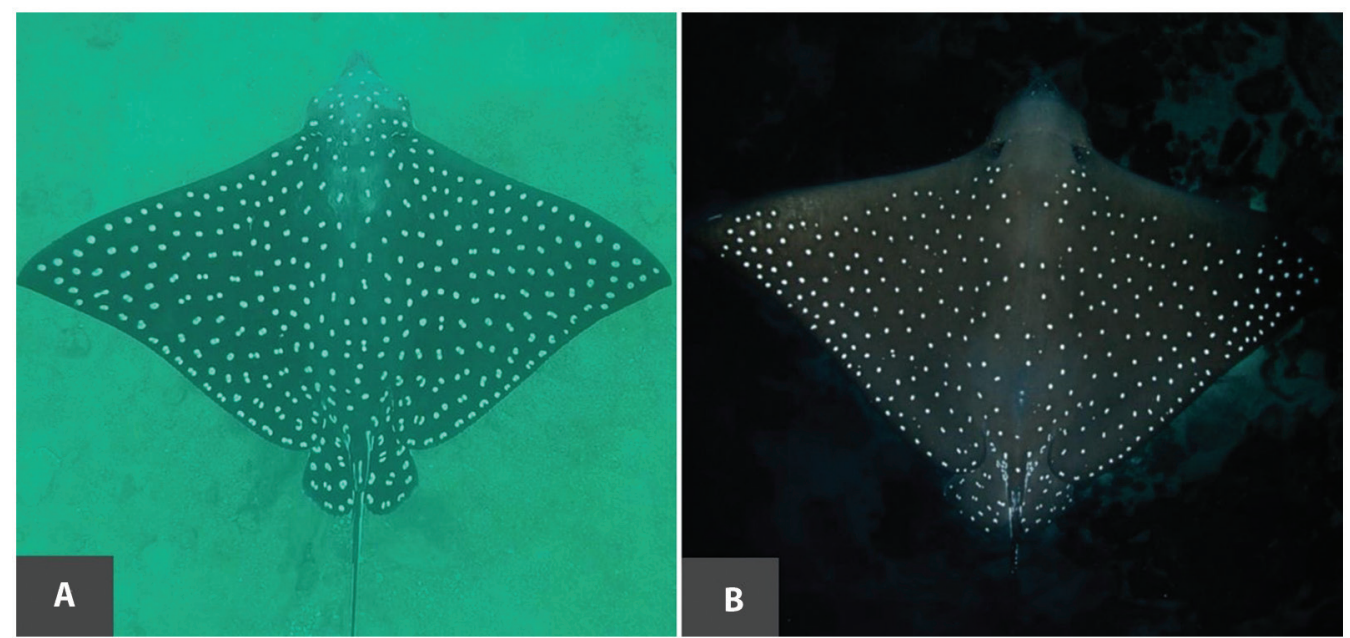

Fig. 5. Continental and oceanic island pattern. In A, an individual of A. laticeps sighted at the sampling site (North Pacific coast of Costa Rica), while in B a different pattern is observed found in Cocos Island. 
with molecular studies may unravel a putative second species in the region (Concha, Caira, Marques, \& Pompert, 2014; Naylor et al., 2012; Sales et al., 2019).

Several genetic studies have been carried out for Aetobatus (Concha et al., 2014; Naylor et al., 2012; Richards et al., 2009; Sales et al., 2019; White et al., 2010), but morphological information is scarce since material from this genus is usually not available in biological collections due their large size. In this context, a general description of the white-spotted pigmentation on the entire dorsal side described by Last et al. (2016) established "white spots or ocelli" for A. laticeps and "white spot to bluish spots" for A. narinari and A. ocellatus. This represents a taxonomic issue with the description from these three allopatric Aetobatus species with similar coloration patterns (Naylor et al., 2012; White, 2014; White et al., 2010). The present study provides an important finding based on the white spot pattern which allows the differentiation of individuals as well as populations. Given the importance of expanding the current information on the white spot pattern in this species and possible A. laticeps complex, further studies are needed in other areas along its distribution, considering the pigmentation pattern among other morphological diagnostic features. Based on pigmentation patterns and molecular markers tools, it would be possible to reassess the taxonomic status of Aetobatus species in the Eastern Tropical Pacific. Besides, the individual marks combined with tagging programs may help to provide unknown demographic information such as population size, movements, and connectivity between different regions.

Ethical statement: authors declare that they all agree with this publication and made significant contributions; that there is no conflict of interest of any kind; and that we followed all pertinent ethical and legal procedures and requirements. All financial sources are fully and clearly stated in the acknowledgements section. A signed document has been filed in the journal archives.

See Digital Appendix at: /

Ver Apéndice digital en: revistas.ucr.ac.cr

\section{ACKNOWLEDGMENTS}

To the NGO Equipo Tora Carey, for their fellow support on the collection of data, especially to their seasonal volunteer Ariadna Ayén-Vouillamoz.

\section{RESUMEN}

\section{Diversidad de patrones de manchas blancas de Aetobatus laticeps (Myliobatiformes: Aetobatidae) en la costa del Pacífico Norte de Costa Rica}

Introducción: La raya águila de manchas blancas del Pacífico, Aetobatus laticeps, se ha separado recientemente de $A$. narinari del Atlántico basándose en pruebas tanto morfológicas como genéticas. Esta especie se caracteriza por un cuerpo oscuro con numerosas manchas blancas en toda su parte dorsal. Considerando el tipo, la forma, el número y la distribución de estas marcas naturales como identificadores potenciales a nivel individual, estudiamos la variación en los patrones de manchas.

Objetivo: Describir y comparar el patrón de manchas blancas (tipo y distribución) de individuos y evaluar su uso potencial como identificadores a nivel individual en especímenes recapturados.

Métodos: Analizamos 54 videos (con 105 fotografías extraídas posteriormente) y 19 registros fotográficos que fueron tomados en diferentes sitios a lo largo de la costa pacífica del norte de Costa Rica.

Resultados: Se identificaron diecisiete tipos distintivos de manchas blancas en todo el lado dorsal de los radios. Se encontraron diferencias significativas entre cada sección principal del cuerpo (aletas pectorales, espalda, cabeza y aletas pélvicas) en el tipo y frecuencia de manchas blancas. El tipo 'punto único' se distribuyó comúnmente en todo el lado dorsal, y el patrón de puntos en las aletas pélvicas fue informativo para identificar 72 individuos.

Conclusiones: El análisis del tipo, la forma y la distribución de las manchas blancas en A. laticeps determinó varias combinaciones de patrones de manchas blancas que se utilizarán para una descripción taxonómica adicional y brindan una identificación potencial del individuo para futuros estudios de población a lo largo de su distribución.

Palabras clave: foto-ID; marcas; morfología; Pacífico Tropical Oriental; descripción; caracterización; batoideos. 


\section{REFERENCES}

Andrzejaczek, S., Meeuwig, J., Rowat, D., Pierce, S., Davies, T., Fisher, R., \& Meekan, M. (2016). The ecological connectivity of whale shark aggregations in the Indian Ocean: a photo-identification approach. Royal Society Open Science, 3, 160455. http://dx.doi. org/10.1098/rsos. 160455

Bassos-Hull, K., Wilkinson, K. A., Hull, P. T., Dougherty, D. A., Omori, K. L., Ailloud, L. E., Morris, J. J., \& Hueter, R. E. (2014). Life history and seasonal occurrence of the spotted eagle ray, Aetobatus narinari, in the eastern Gulf of Mexico. Environmental Biology of Fishes, 97, 1039-1056. http://dx.doi.org/10.1007/ s10641-014-0294-Z

Bussing, W. A., \& López, M. I. (2005). Peces de la Isla del Coco y peces arrecifales de la costa Pacífica de América Central Meridional: Guía ilustrada. San Jose, Costa Rica: Editorial de la Universidad de Costa Rica.

Carrera-Treviño, R., Lira-Torres, I., Martínez-García, L., \& López-Hernández, M. (2016). The jaguar Panthera onca (Carnivora: Felidae) in "El Cielo" Biosphere Reserve, Tamaulipas, Mexico. Revista de Biología Tropical, 64(4), 1451-1468 https://doi.org/10.15517/ rbt.v64i4.21880

Cerutti-Pereyra, F., Bassos-Hull, K., Arvizu-Torres, X., Wilkinson, K. A., García-Carrillo, I., Perez-Jimenez, J. C., \& Hueter, R. E. (2017). Observations of spotted eagle rays (Aetobatus narinari) in the Mexican Carribbean using photo-ID. Environmental Biology of Fishes, 101, 237-244. https://doi.org/10.1007/ s10641-017-0694-y

Chávez, E. J., Heidemeyer, M., Arauz, R., Arauz, D., Mora, R. V., Molina, J. L., \& Hernandez, S. (In press). Ocurrence of the roughskin Eagle ray Aetomylaeus asperrimus (Chondrichthyes: Myliobatidae) along the Pacific coast of northern Costa Rica. Marine Biodiversity Records.

Concha, F., Caira, J., Marques, F. P. L., \& Pompert, J. (2014). New findings on Latinamerican misidentified batoid species: implications for conservation management. In P. A. Mejía-Falla, V. Ramírez, \& A. F. Navia (Eds.), Libro de resúmenes IV Encuentro colombiano sobre condrictios (pp. 52). Cali, Colombia: Fundación SQUALUS.

Denis-Ávila, D., \& Cruz-Flores, D. (2017). Algoritmo para la foto identificación de individuos en lepidópteros diurnos cubanos con patrones de manchas. Revista Cubana de Zoología, 505, 1-14.

Fiedler, P. C. (2002). El ciclo anual y los efectos biológicos del Domo de Costa Rica. Deep Sea Research Part I. Oceanographic Research Papers, 49(2), 321-338.

Flowers, K., Henderson, A. C., Lupton, J. L., \& Chapman, D. (2017). Site affinity of whitespotted eagle rays
Aetobatus narinari assessed using photographic identification. Journal of Fish Biology, 90(5), 1337-1349.

Garrison, G. (2005). Peces de la Isla del Coco. San José, Costa Rica: Editorial INBio.

Gill, T. (1867). XIII. Note on the Family of Myliobatoids, and on a New Species of Aetobatis. Annals of the New York Academy of Sciences, 8(1), 135-138.

González-Ramos, M. S., Santos-Moreno, A., Rosas-Alquicira, E. F., \& Fuentes-Mascorro, G. (2016). Validation of photo-identification as a mark-recapture method in the spotted eagle ray Aetobatus narinari. Journal of Fish Biology, 90(3), 1021-1030.

Hammer, Ø., Harper, D. A., \& Ryan, P. D. (2001). Palaeontological statistics software package for education and data analysis. Palaeontologia Electronica, 4(1), 9-18.

Last, P., Naylor, G., Séret, B., White, W., de Carvalho, M., \& Stehmann, M. (2016). Rays of the World. Victoria, Australia: Csiro Publishing.

McEachran, J. D., De Carvalho, M. R., \& Carpenter, K. E. (2002). Batoid fishes. The living marine resources of the Western Central Atlantic, 1, 507-589.

Musick, J. A., \& Bonfil, R. (Eds.). (2005). Management techniques for elasmobranch fisheries). FAO Technical Paper, No. 474. Rome, Italy: FAO.

Naylor, G. J. P., Caira, J. N., Jensen, K., Rosana, K. A. M., White, W. T., \& Last, P. R. (2012). A DNA SequenceBased approach to the identification of shark and ray species and its implications for global elasmobranch diversity and parasitology. Bulletin of the American Museum of Natural History, 367, 84-85.

Ornés, A. S., Herbst, A., Spillner, A., Mewes, W., \& Rauch, M. (2014). A standardized method for quantifying eggshell spot patterns. Journal of Field Ornithology, 85(4), 397-407.

Palmeira, A. R. O., \& Rosa, R. S. (2014). Caracterização morfométrica de embriões de Aetobatus narinari capturados no litoral oeste do ceará, Brasil. In P. A. Mejía-Falla, V. Ramírez \& A. F. Navia. (Eds.), Libro de resúmenes IV Encuentro colombiano sobre condrictios (pp. 95). Cali, Colombia: Fundación SQUALUS.

Porsiel, N. (2018). Abundance and habitat use of rays in shallow waters of the northern Pacific coast of Costa Rica (master's thesis). Universität Hamburg, Hamburg, Germany.

Richards, V. P., Henning, M., Witzell, W., \& Shivji, M. S. (2009). Species Delineation and Evolutionary History of the Globally Distributed Spotted Eagle Ray (Aetobatus narinari). Journal of Heredity, 100(3), 273-283. 
Robertson, D. R., \& Allen, G. (2015). Shorefishes of the Tropical Eastern Pacific online information system. Version 2.0. Smithsonian Tropical Research Institute, Balboa, Panamá. https://biogeodb.stri.si.edu/sftep/en/ pages

Sales, J. B. L., Negrão de Oliveira, C., Rosa dos Santos, W. C., Rotundo, M. M., Ferreira, Y., Ready, J., Sampaio, I., Oliveira, C., Cruz, V., Lara-Mendoza, R. E., \& Rodrigues-Filho, L. F. S. (2019). Phylogeography of eagle rays of the genus Aetobatus: Aetobatus narinari is restricted to the continental western Atlantic Ocean. Hydrobiologia, 836, 169-183.

Sellas, A. B., Bassos-Hull, K., Pérez-Jiménez, J. C., Angulo-Valdés, J. A., Bernal, M. A., \& Hueter, R. E. (2015). Population Structure and Seasonal Migration of the Spotted Eagle Ray, Aetobatus narinari American Genetic Association. Journal of Heredity, 106(3), 266-275.

Speed, C. W., Meekan, M. G., \& Bradshaw, C. J. A. (2007). Spot the match - wildlife photo-identification using information theory. Frontiers in Zoology, 4(1), 2.
Tillett, B. J., Meekan, M. G., Parry, D., Munksgaard, N., Field, I. C., Thorburn, D., \& Bradshaw, C. J. (2011). Decoding fingerprints: elemental composition of vertebrae correlates to age-related habitat use in two morphologically similar sharks. Marine Ecology Progress Series, 434, 133-142.

Ullas-Karanth, K., \& Nichols, J. D. (1998). Estimation of Tiger Densities in India Using Photographic Captures and Recaptures. Ecology, 79(8), 2852-2862.

White, W. T. (2014). A revised generic arrangement for the eagle ray family Myliobatidae, with definitions for the valid genera. Zootaxa, 3860(2), 149-166.

White, W. T., Last, P. R., Naylor, G. J., Jensen, K., \& Caira, J. N. (2010). Clarification of Aetobatus ocellatus (Kuhl, 1823) as a valid species, and a comparison with Aetobatus narinari (Euphrasen, 1790) (Rajiformes: Myliobatidae). Descriptions of new sharks and rays from Borneo. CSIRO Marine and Atmospheric Research Paper, 32, 141-164. 